\title{
CANADIAN ANAESTHETISTS' SOCIETY MEDAL
}

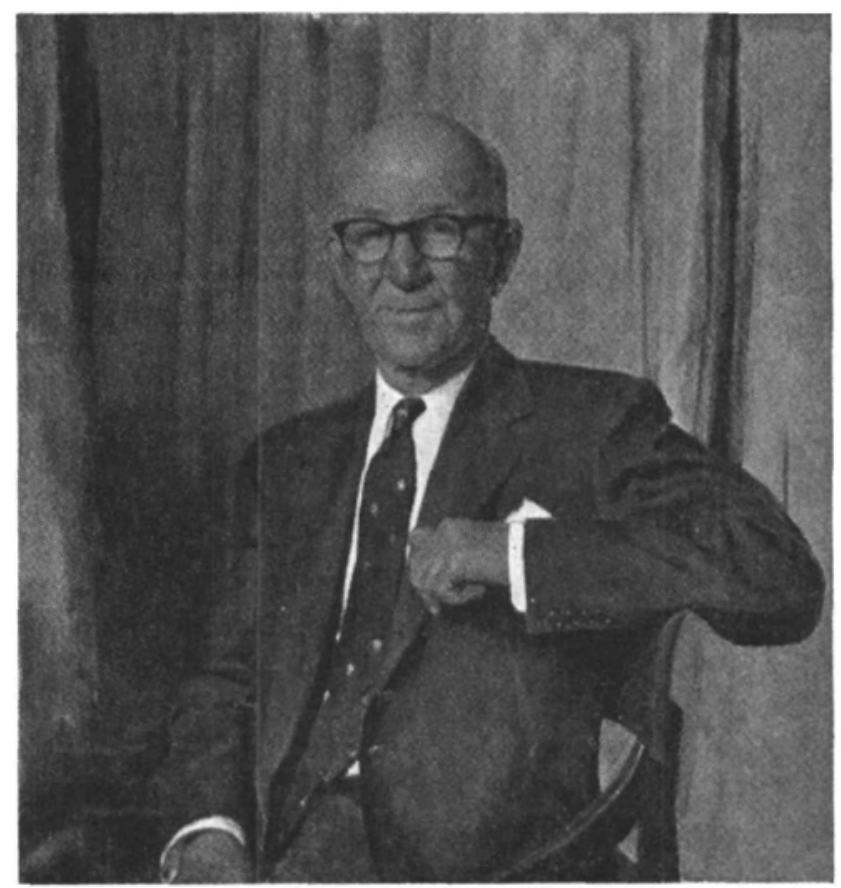

Sir Robert Reynolds Macintosh

Robert Reynolds Macintosh was born in Timaru, New Zealand, on October 17, 1897. On finishing school he sailed for Great Britain to join the Royal Flying Corps, was trained as a fighter pilot, and after a brief career in the air was shot down over enemy territory and became a prisoner of war.

After the First World War he took his medical training at Guy's Hospital in London, qualifying in 1924. He then embarked on surgical training, intending to embrace a surgical career. During his training he gave dental anaesthetics at Guy's Hospital, and by the time he had acquired the F.R.C.S. his anaesthetic practice was too good to be renounced. A number of hospital appointments in anaesthesia followed, including one in Montevideo. In the late 1920's he joined with two colleagues to form the first anaesthetic partnership in Britain, and was the senior member of a most successful practice in London.

In 1937 Dr. Macintosh was appointed to the new Nuffield Chair of Anaesthetics at Oxford University. This was the first chair of anaesthesia in Europe, and the new professor began his tenure by travelling to the United States to visit teaching departments of anaesthesia in that country. This was the first of innumerable such journeys throughout his career, which took him to all quarters of the globe, and frmly established him as the universal ambassador of sound anaesthetic practice and teaching.

During World War II Professor Macintosh was consultant to the Royal Air Force in the rank of Air Commodore. Throughout the war years the influence 
of his department at Oxford became tremendously important not only in the United Kingdom but to the future of anaesthesia in North America. Courses of instruction were provided for young officers in the British, Canadian, and American forces stationed in the United Kingdom, and the stimulus provided by Professor Macintosh and his colleagues in those days is apparent in the number of these young men who now hold senior responsibility in academic departments of anaesthesia in Canada and the United States. After 1945 many young European physicians received their initial training in anaesthesia under Professor Macintosh's direction in the Nuffield Department at Oxford, and there is scarcely a department of anaesthesia in Europe which does not in large part owe its origins to his influence. In addition to his other activities, Professor Macintosh has published a number of books in the field of anaesthesia, which have been translated into other languages and have become standard study material for students of anaesthesia throughout the world.

Professor Macintosh has received honorary doctorates from Aix-Marseilles, Buenos Aires, and Cardiff. He has been honoured by the Award of the Henry Hill Hickman Medal, the Clover Medal, and the Snow Medal. He is an honorary fellow of the Faculties of Anaesthetists of Australia, Ireland, and Great Britain. $\mathrm{He}$ is an honorary fellow of the Royal Society of Medicine and of Pembroke College, Oxford. He has served as president of the Section of Anaesthetics of the Royal Society of Medicine, and was president of the Section of Anaesthetics of the British Medical Association at the annual meetings held at Harrogate and the joint meeting with the Canadian Medical Association in Toronto in 1955. His contributions to his profession and to society have been recognized by a knighthood. Sir Robert retired from the Nuffield Chair of Anaesthetics in Oxford in 1965. It is evident that his retirement was a formality of which he himself has taken little notice, since he remains active and continues as before his efforts to extend better anaesthesia to all areas of the world.

Robert Reynolds Macintosi naquit à Timaru, Nouvelle Zélande, le 17 octobre 1897. A la fin de ses études, il partit pour la Grande Bretagne où il rejoignit le Royal Flying Corps; il reçut une formation de pilote de combat et, après une brève carrière dans l'aviation, il fut descendu en territoire ennemi et devint prisonnier de guerre.

Après la première guerre mondiale, il reçut son éducation médicale au Guy's Hospital de Londres, où il gradua en 1924. Alors il entreprit de se perfectionner en chirurgie avec l'intention de faire une carrière chirurgicale. Duront son stage en chirurgie, il faisait de l'anesthésie pour la chirurgie dentaire; et lorsqu'il obtint son F.R.C.S., sa pratique de l'anesthésie était trop bien maitrisée pour être abandonnée. Il obtint par la suite un certain nombre de postes en anesthésie, entre autres à Montevideo. Vers la fin des années 20 , il se joignit à deux collègues pour former la première équipe d'anesthésistes de Grand Bretagne, et il était le doyen d'un groupe qui eut beaucoup de succès à Londres.

En 1937, le docteur Macintosh fut désigné à la nouvelle Nuffield Chair of Anaesthetics de l'Université d'Oxford. C'était la première chaire d'anesthésie en 
Europe, et le nouveau professeur commença d'abord par voyager à travers les Etats-Unis pour visiter les centres d'enseignement de l'anesthésie dans ce pays. Ce fut le premier d'une série de voyages qu'il fit au cours de sa carrière, voyages qui le conduisirent aux quatre coins du globe, et qui le consacrèrent comme l'ambassadeur universel de la pratique et de l'enseignement d'une anesthésie de qualité.

Durant la seconde guerre mondiale, le professeur Macintosh était consultant à la Royal Air Force avec le grade de Commodore de l'Air. Durant ces années de guerre, l'influence de son départment d'Oxford devint très important non seulement pour le Royaume-Uni mais aussi pour l'avenir de l'anesthésie en Amérique du Nord.

On organisa des cours de perfectionnement aux jeunes officiers des armées Britaniques, Canadiennes et Américaines postées dans le Royaume Uni, et l'encouragement fourni alors par le professeur Macintosh et ses collaborateurs se manifeste aujourd'hui dans la personne de ces jeunes qui maintenant occupent des postes de commande dans les départements d'anesthésie des Universités du Canada et des Etats-Unis. Après 1945, beaucoup de jeunes médecins Européens ont reçu les éléments de leur formation en anesthésie sous la direction du professeur Macintosh à Oxford dans le Nuffield Department; il y a très peu de départements d'anesthésie en Europe qui à leur début n’ont pas subi son influence. En plus de ses autres activités, le professeur Macintosh a publié, dans le domaine de l'anesthésie, un certain nombre de livres qui ont été traduits en d'autres langues et qui sont devenus essentiels aux étudiants en anesthésie à travers le monde.

Le professeur Macintosh a reçu des doctorats honorifiques d'Aix-Marseilles, de Buenos Aires et de Cardiff. Il a eu l'honneur de recevoir la Médaille Henry Hill Hickman, la Clover Medal et la Snow Medal. Il est Honorary Fellow des Facultés des Anesthésistes d'Australie, d'Irlande, et de Grande Bretagne. Il est Honorary Fellow de la Royal Society of Medicine et du Pembroke College, Oxford. Il a été président de la Section d'Anesthésie de la Royal Society of Medecine, et il était président de la Section d'Anesthésie de la British Medical Association à l'assemblée annuelle tenue à Harrowgate et à l'assemblée conjointe avec l'Association Médicale Canadienne à Toronto en 1955. On a reconnu ses contributions à sa profession et à la société en l'élevant à la Chevalerie. En 1965, Sir Robert abandonna la Chaire d'Anesthésie d'Oxford. Il est évident que cette retraite n'était qu'une formalité dont il a fait peu de cas lui-même, puisqu'il demeure très actif et qu'il poursuit comme toujours ses efforts pour la promotion de l'anesthésie à travers le monde. 


\section{CANADIAN ANAESTHETISTS' SOCIETY MEDAL}

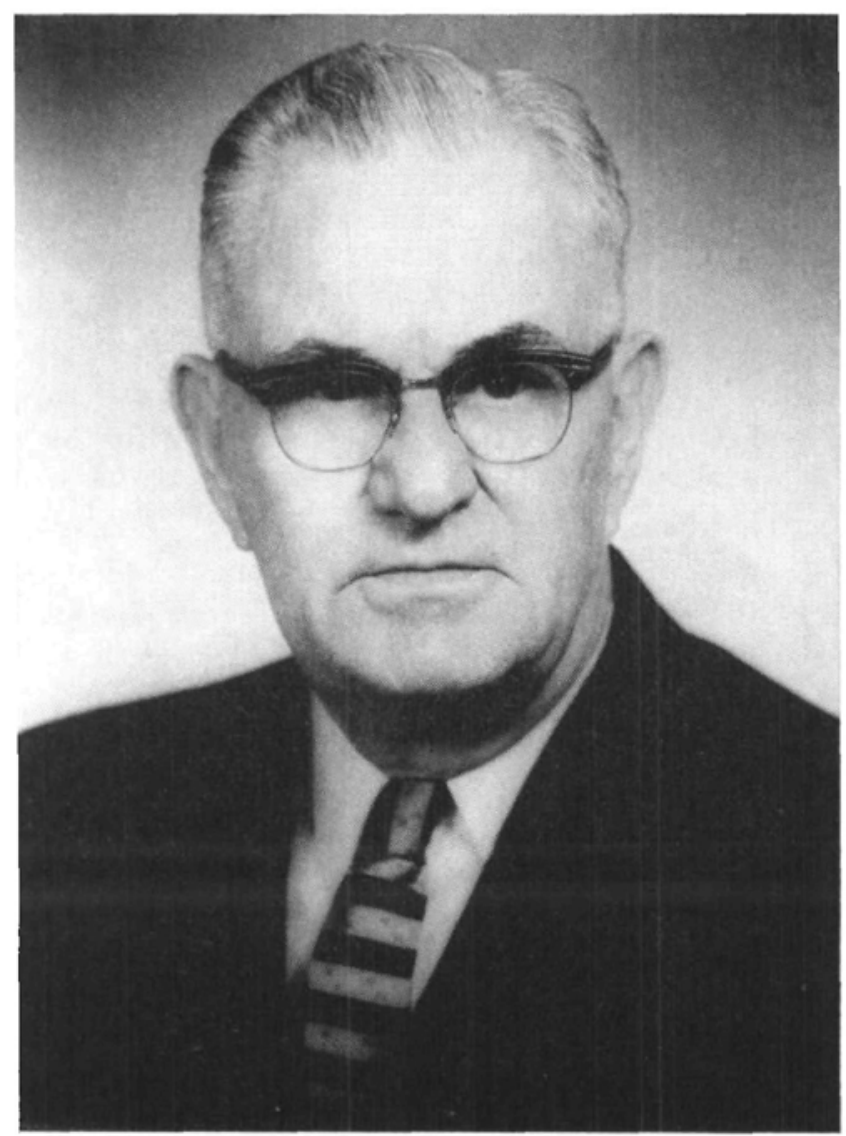

Dr. JoHN SILAS Lundy

Dr. John Srlas Lundy of Seattle, Washington, internationally known specialist in anaesthesiology, was born in Inkster, North Dakota, on July 6, 1894, the son of Lila Woods Lundy and Dr. Fred G. Lundy. As a boy five years old he began to take a lively interest in medicine and determined to become a doctor. $\mathrm{He}$ received the degree of bachelor of arts in 1917 from the University of North Dakota, and that of doctor of medicine from the Rush Medical College of the University of Chicago in 1919. In 1919 and 1920 he was an intern in the Harper Hospital in Detroit, Michigan; and from 1920 to 1924 he was engaged in the private practice of medicine in Seattle.

On April 1, 1924, at the invitation of Dr. William J. Mayo, Dr. Lundy moved to Rochester, Minnesota, to found the Section of Anesthesiology at the Mayo Clinic. He was head of this department until 1952, when he became a senior consultant. He retired from the Mayo Clinic on October 1, 1959, and removed to Chicago, Illinois, where he continued to practise his specialty. In 1964 he moved back to Seattle, where he now resides. 
Dr. Lundy was appointed an instructor in anaesthesiology in the Mayo Graduate School of Medicine, University of Minnesota at Rochester, in 1925, an assistant professor in 1928, an associate professor in 1931, and professor in 1934. He established the first laboratory of gross anatomy to be used at the Mayo Clinic.

As a result of his extensive original researches in anaesthesiology and the volume of anaesthesia required at the Mayo Clinic, Dr. Lundy early became recognized as an international authority in this field of medicine. In addition, he was a pioneer in the graduate training of young physicians in anaesthesiology at the Mayo Clinic, and he was one of the founders of the American Board of Anesthesiology, serving as president in 1942.

In 1923 Dr. Lundy developed the specifications for, and caused to be built, a four-control machine for the administration of anaesthetic gases; between 1922 and 1932 he developed apparatus for artificial respiration for surgical patients; and in 1925 he devised a special syringe and equipment for local anaesthesia. His theory and practice of "balanced anaesthesia," which he introduced in 1925, is widely known. In 1932 he introduced a solution of procaine for use in spinal anaesthesia, and in 1934 he contributed to the advancement of intravenous anaesthesia by demonstrating the advantages of several new barbiturates when they are employed intermittently by the intravenous route. On June 18, 1934, he introduced the use of pentothal sodium, an intravenous anaesthetic agent now used in surgery all over the world. In 1935 he established the first blood bank in the United States. On March 17, 1942, he opened the first postanaesthesia recovery room in the world at St. Mary's Hospital, Rochester, embodying a practice currently in use throughout the world. He is recognized as an authority on the mass treatment of casualties in time of disaster.

Many honours, national and international, have come to Dr. Lundy for his pre-eminence in his chosen field. In 1943 the Hahnemann Medical College of Philadelphia conferred upon him the honorary degree of doctor of laws, and in 1948 the University of North Dakota awarded him the honorary degree of doctor of science. In 1948 the state of North Dakota presented him with an honorary licence to practise medicine in that state and in the same year he was the recipient of the distinguished service medal of the American Society of Anesthesiologists.

Dr. Lundy organized the Anesthesia Travel Club in 1929, an organization which at that time brought together on a regular basis virtually all the recognized specialists in Anaesthesia of the United States and Canada. In 1952 at his instigation this Travel Club became the Academy of Anesthesiology. He served as president of the American Society of Anesthesiologists in 1946, and he has been chairman and secretary of the Section of Anesthesiology of the American Medical Association. He is a member of the Cuban National Society of Anesthesiology and the Société française d'anethésie et analgésie; he is a corresponding member of the Sociedad de estudior clinicas de la Habana and a corresponding fellow of the Association of Anaesthetists of Great Britain and Ireland. He is also a member of the Minnesota State Medical Association, the Minnesota Society of Anesthesiologists, the American Society for Pharmacology and Experimental Therapeutics, the International Anesthesia Research Society, the Alumni Association of the Mayo Graduate School of Medicine, the Society of the Sigma $\mathrm{Xi}$, the 
Beta Theta Pi academic fraternity, and the Alpha Kappa Kappa professional medical fraternity.

In 1955 Dr. Lundy was appointed a member of the medical advisory committee of the American National Red Cross. He has served as consultant to the Surgeon of the Fifth American Army, and consultant in anaesthesiology to the Shriners Hospitals for Crippled Children.

During World War II Dr. Lundy was a national consultant in anaesthesia for the Wartime Graduate Medical Meetings (a government project) held in Washington, D.C. He also served as a civilian consultant in anaesthesiology to the Office of the Surgeon General of the U.S. Army, and he was a member of the Subcommittee on Anaesthesia of the National Research Council in Washington, D.C.

In April, 1957, he was appointed a contractual consultant to the Surgeon General of the U.S. Navy, and in company with a number of other outstanding specialists he lectured on anaesthesiology at various army and navy medical installations in Hawaii, Guam, and Japan.

Dr. Lundy is the author of Clinical Anesthesia, published in 1942, and he has contributed more than 600 papers on anaesthesiology and related subjects to the medical literature.

Dr. Lundy was married on September 5, 1925 to Miss Lenore Mittelstadt, of Saint Paul, Minnesota. Mrs. Lundy died on December 6, 1965. Dr. Lundy has three children: Richard Allen; Joan Lenore (Mrs. Donald Robinson); and John Charles.

Le docteur John Silas Lundy, de Seattle, Washington, anesthésiste de renommée internationale, naquit à Inkster, North Dakota, le 6 juillet 1894; il était le fils de Lila Woods Lundy et du docteur Fred G. Lundy. Dès l'âge de cinq ans, il manifesta un vif intérêt pour la médecine et il résolut de devenir médecin. Il reçut son diplôme de bachelier es arts de l'Université du North Dakota en 1917, et celui de docteur en médecine du Rush Medical College de l'Université de Chicago en 1919. En 1919 et 1920, il fut interne au Harper Hospital, à Détroit, Michigan; de 1920 à 1924, il fit de la médecine générale à Seattle.

Le 1 avril 1924, à l'invitation du docteur William J. Mayo, le docteur Lundy s'installa à Rochester Minnesota, pour fonder la Section d'Anesthésiologie à la Clinique Mayo. Il demeura chef de ce département jusqu'en 1952, alors qu'il devint consultant sénior. Il quitta la Clinique Mayo le 1 octobre 1959 et s'établit à Chicago, Illinois, où il continua à pratiquer sa spécialité. En 1964, il retourna à Seattle, où il demeure maintenant.

Le docteur Lundy fut chargé de cours en anesthésiologie au Mayo Graduate School of Medicine de l'Université du Minnesota à Rochester en 1925, assistant professeur en 1928, professeur agrégé en 1931, et professeur titulaire en 1934. Il établit le premier laboratoire d'anatomie macroscopique à être utilisé à la Clinique Mayo.

A la suite de ses travaux de recherches en anesthésiologie et à cause du nombre d'anesthésies requises à la Clinique Mayo, le docteur Lundy fut bientôt reconnu 
comme une autorité internationale dans ce domaine de la médecine. De plus, il fut un pionnier dans la formation de jeunes spécialistes en anesthésie à la Clinique Mayo, et il fut un des fondateurs de l'American Board of Anesthesiology, dont il fut président en 1942 .

En 1923, le docteur Lundy établit les principes d'un appareil à quatre contrôles pour l'administration des gaz anesthésiques, et fit construire tel appareil; de 1922 à 1932, il perfectionna un appareil à respiration artificielle pour les malades soumis à la chirurgie; et, en 1925, il inventa une seringue spéciale ainsi qu'un nécessaire à anesthésie locale. Sa théorie et pratique de l' "anesthésie balancée," qu'il présenta en 1925, est bien connue. En 1932, il présenta une solution de procaïne destinée à l'anesthésie rachidienne, et en 1934, il contribua à l'avancement de l'anesthésie intra-veineuse en montrant les avantages de plusieurs nouveaux barbituriques si on les utilise par voie veineuse de façon intermittente. Le 18 juin 1934, il utilisa pour la première fois le pentothal sodique, agent anesthésique intraveineux maintenant en usage dans le monde entier. En 1935, il établit la première banque de sang des Etats-Unis. Le 17 mars 1942, il ouvrit la première salle de réveil du monde au St. Mary's Hospital, à Rochester, ouvrant la voie à une pratique maintenant courante à travers le monde. Il est reconnu comme une autorité dans le traitement intensif de blessés en cas de désastre.

Beaucoup d'honneurs, dans son pays et à l'étranger, ont été rendus au docteur Lundy pour sa distinction dans le domaine qu'il a choisi. En 1943, le Hahnemann Medical College de Philadelphie lui conféra le titre de docteur en droit honoris causa, et en 1948 l'Université du North Dakota lui décerna le titre de docteur en science. En 1948, l'état du North Dakota lui présenta une licence honoraire lui permettant de pratiquer la médecine dans cet état et, la même année, il fut le récipiendaire de la distinguished service medal de l'American Society of Anesthesiologists.

En 1929, le docteur Lundy mit sur pieds l'Anaesthesia Travel Club, organisation qui à ce moment là rapprocha pratiquement tous les spécialistes reconnus des Etats-Unis et du Canada. En 1952, à sa suggestion ce Travel Club devint l'Academy of Anesthesiology. En 1946, il présida aux destinées de l'American Society of Anesthesiologists; il fut aussi président et secrétaire de la section d'anesthésie de l'American Medical Association. Il est membre de la Société nationale cubaine d'anesthésiologie, et de la Société française d'anesthésie et analgésie; il est membre correspondant de la Sociedad de estudior clinicas de la Habana et correspondant associé de l'Association des anesthésistes de Grande Bretagne et d'Irlande. Il est aussi membre de la Minnesota State Medical Association, de la Minnesota Society of Anesthesiologistes, de l'American Society for Pharmacology and Experimental Therapeutics, de l'International Anesthesia Research Society, de l'Alumni Association of the Mayo Graduate School of Medicine, de la Society of the Sigma Xi, de la Beta Theta Pi fraternité academique et de la Alpha Kappa Kappa fraternité professionnelle médicale.

En 1955, le docteur Lundy fut désigné comme membre du comité consultatif médical de la Croix rouge nationale américaine. Il a servi comme consultant au Surgeon of the Fifth American Army, et consultant en anesthésiologie au Shriners Hospital for Crippled Children. 
Durant la seconde guerre mondiale, le docteur Lundy était consultant national en anesthésie pour les Wartime Graduate Medical Meetings (projet gouvernemental) tenus à Washington, D.C. Il servit aussi comme consultant civil en anesthésiologie au bureau du chirurgien général de l'armée américaine, et il était membre du Subcommittee on Anesthesia of the National Research Council à Washington, D.C.

En avril 1957, il fut désigné comme consultant au chirurgien général de la marine des Etats-Unis, et avec un certain nombre d'autres spécialistes distingués il donna des conférences sur l'anesthésiologie à divers centres médicaux de l'armée et de la marine, à Hawaï, à Guam et au Japon.

Le docteur Lundy est l'auteur de Clinical Anesthesia publié en 1942, et il a contribué à plus de 600 publications sur l'anesthésiologie ou sur des sujets qui s'y rattachent dans la littérature médicale.

Le 5 septembre 1925, le docteur Lundy a épousé Mlle Lenore Mittelstadt, de Saint-Paul, Minnesota. Mme Lundy est décédée le 6 décembre 1965. Le docteur Lundy a trois enfants: Richard Allen, Joan Lenore (Mme Donald Robinson) et John Charles. 


\section{CANADIAN ANAESTHETISTS' SOCIETY MEDAL}

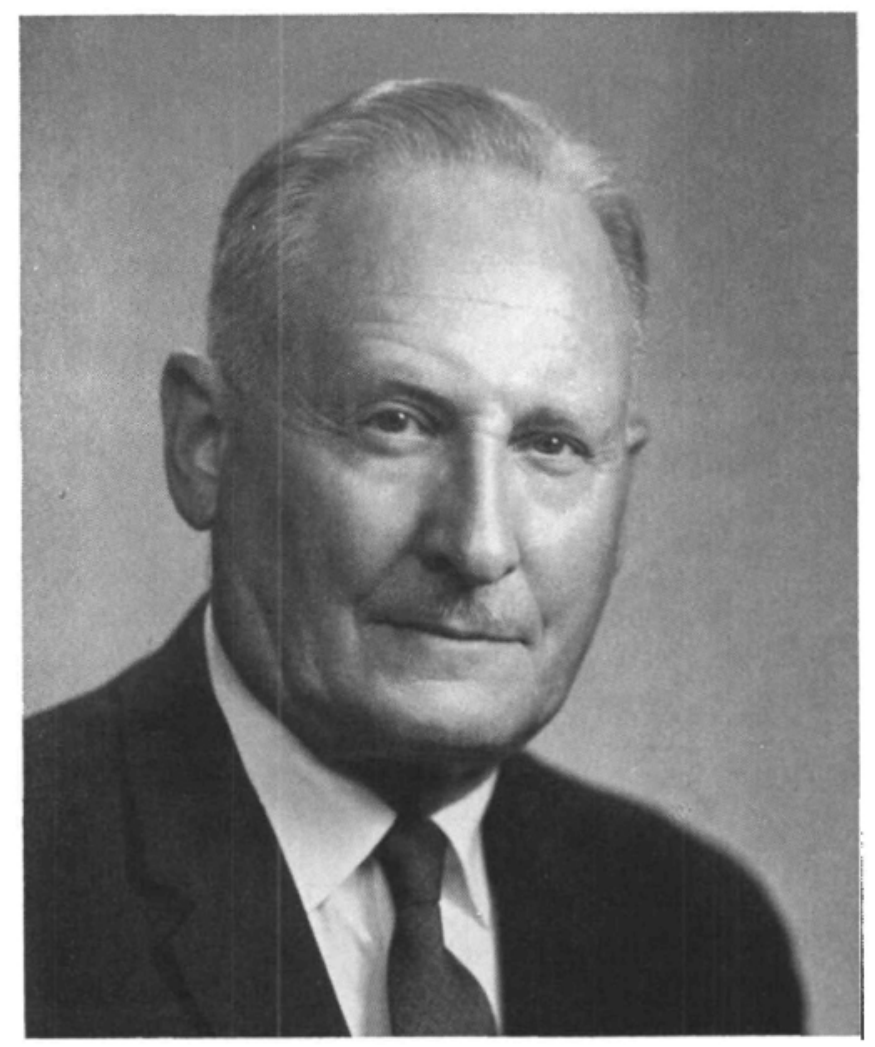

Dr. Stanlex Minto Campbell

Dr. Campbell was born in Toronto on May 7, 1899, the son of William Charles Campbell and his wife Christie Matheson. He received his elementary education at the Toronto Model School and his secondary education at the University of Toronto Schools. As a student at University College during World War I he qualified for a commission through the Canadian Officers Training Corps, and in March 1917 was appointed to the King's Royal Rifle Corps of the British Army as a Second Lieutenant. On returning to Toronto in April 1919, he enrolled in the Faculty of Medicine at the University of Toronto, and graduated with the M.B. degree in 1924. Following a junior internship at the Toronto General Hospital, he commenced a general practice in Toronto in 1925. In 1926 he was appointed to the Department of Anaesthesia of the Toronto General Hospital and of the University of Toronto. In 1952 he was appointed associate professor and head of that department, and Anaesthetist-in-Chief at the Toronto General Hospital. This appointment coincided with the emergence of the Department of Anaesthesia at Toronto as an autonomous department, and under his leadership the postgraduate teaching programme of the department was expanded and reorganized, culminating in the development and recognition by the Senate of the 
University of Toronto of a formal academic diploma course in anaesthesia. Dr. Campbell retired from the University in 1961.

Prior to World War II Dr. Campbell was a militia officer in the Royal Canadian Army Medical Corps. In September 1939 he joined the Fifteenth Canadian General Hospital with the rank of Major and served in that unit in the United Kingdom until October 1942, when he returned to his civilian practice.

Dr. Campbell was president of the Canadian Anaesthetists' Society in 1950-51, and on his retirement from the University of Toronto he became secretarytreasurer of the Society, a post which he still fills with great distinction. He was president of the Academy of Anaesthesiology in 1965-66; he is a corresponding fellow of the Association of Anaesthetists of Great Britain and Ireland, and a member of the Canadian Medical Association, the Ontario Medical Association, the Academy of Medicine of Toronto, and the International Anaesthesia Research Society.

Dr. Campbell was awarded the Certificate for Meritorious Achievement of the International Anaesthesia Research Society in 1958. For many years he has been interested and involved in the work of the St. John Ambulance Association, and has been honoured by the Award of the Order of St. John of Jerusalem in the rank of Serving Brother.

Dr. Campbell was married on June 17, 1927, to Jane Forsythe Rankin. He is the proud father of two sons, and has three grandchildren.

Le docteur Campbeul naquit à Toronto le 7 mai 1899; il est le fils de William Charles Campbell et de madame Campbell née Christie Matheson. Il reçut son éducation primaire au Toronto Model School et son éducation secondaire dans les Ecoles affiliées à l'Université de Toronto. Comme étudiant au University College durant la première guerre mondiale, il se mérita une commission du Canadian Officers Training Corps, et en mars 1917 il fut assigné au King's Royal Rifle Corps de l'armée brittanique comme second lieutenant. A son retour à Toronto en avril 1919, il s'inscrivit à la Faculté de médecine de l'Université de Toronto, et il obtint son M.B. en 1924. Après son internat junior au Toronto General Hospital, il débuta en pratique générale à Toronto en 1925. En 1926, il fut attaché au Département d'anesthésie du Toronto General Hospital et de l'Université de Toronto. En 1952, il devint professeur agrégé et chef du département, et anesthésiste-en-chef au Toronto General Hospital. Cette nomination a cö̈ncidé avec la création du Département d'Anesthésie à Toronto comme département autonome; sous la direction du docteur Campbell, le programme d'enseignement post-universitaire fut développé et réorganisé; il atteignit son point culminant lorsque le Sénat de l'Université de Toronto a complété et reconnu un cours d'anesthésie pour l'obtention d'un certificat universitaire. Le docteur Campbell a démissionné de l'Université en 1961.

Avant la deuxième guerre mondiale, le docteur Campbell était officier du Royal Canadian Army Medical Corps. En septembre 1939, il joignit le Fifteenth Canadian General Hospital portant le grade Major, et il servit dans cette unité au Royaume-Uni jusqu'en octobre 1942, alors qu'il revint à la vie civile. 
Le docteur Campbell a été président de la Société canadienne des anesthésistes en $1950-51$, et à sa retraite de l'Université de Toronto, il devint secrétairetrésorier de la Société, fonction qu'il remplit encore avec la plus haute compétence. En 1965-66, il fut président de l'Academy of anaesthesiology; il est membre correspondant de l'Association des anesthésistes de Grande-Bretagne et d'Irlande, membre de l'Association médicale canadienne, de l'Ontario Medical Association, de l'Académie de médecine de Toronto et de l'International Anaesthesia Research Society.

En 1958, on a décerné au docteur Campbell le certificate for Meritorious Achievement de l'International Anaesthesia Research Society. Durant plusieurs années, il s'est intéressé activement au travail de la St. John Ambulance Association, et il eut l'honneur de recevoir l'Ordre de Saint-Jean de Jérusalem avec le titre de Frère Servant.

Le 17 juin 1927, le docteur Campbell avait épousé Mlle Jane Forsythe Rankin. Il est l'heureux père de deux fils, et il a trois petits enfants. 